How to cite: Sălăjan, L., Gogoașe Nistoran, D. E. (2019) The Characteristics of the Historical Floods from the Years 1974 and 1975 in the Bâsca Basin. 2019 "Air and Water - Components of the Environment" Conference Proceedings, Cluj-Napoca, Romania, p. 407-418, DOI: 10.24193/AWC2019_40.

\title{
THE CHARACTERISTICS OF THE HISTORICAL FLOODS FROM THE YEARS 1974 AND 1975 IN THE BÂSCA BASIN
}

\author{
Lidia S $\breve{A L} \breve{A J A} N^{I}$ 凹, Daniela Elena GOGOAȘE NISTORAN ${ }^{2}$
}

DOI: $10.24193 / A W C 2019 \_40$

\begin{abstract}
The floods that took place in the Bâsca river basin over time had short and medium duration, the flooding generated by them having had significant consequences on social life, economic activities and environment. Short and medium duration floods generally occur during summer and last for a total of 2- 6 days. These are due to heavy rainfalls $(100-300 \mathrm{~mm}$ ), with high intensity (due to atmospheric instability, thermal conventions and cyclone formation over the Black Sea). The largest floods in the Bâsca river basin occurred in the years 1974, 1975, 1991 and 2005. In this study, the historical floods from June 1974 and July 1975 were analysed on the rivers: Bâsca Mare (Varlaam I hydrometric station), Bâsca Mică (Varlaam II hydrometric station) and Bâsca (the Bâsca Roziliei hydrometric station). In the generation of floods within this hydrographic basin, the geographic factors such as relief, geological formations and lithology, hydrography, vegetation, soil, climate and anthropic activity are of particular importance.
\end{abstract}

Keywords: flood, flooding, retrograde cyclone, precipitation, flood risk management.

\section{INTRODUCTION}

The basin of the Bâsca River is part of the upper basin of the Buzău River and is located within the Curvature Carpathians. The massifs over which this water catchment area overlaps are: Penteleu, Podul Calului, Ivăneţ and some of the Vrancea Mountains, belonging to the external flysch and are made up of an alternation of sandstones, marches, clays, bituminous shale and more rarely from Bucegi conglomerates lined up NE - SV direction (Posea and Ielenicz, 1971).

The Bâsca River Basin has an elongated shape in the general NNE - SSV drainage direction, which reduces the concentration time of the rainfall on the basin and the way flood form. The altitudes in this basin vary between $350-1800 \mathrm{~m}$, the average altitude is approx. $1100 \mathrm{~m}$. High values of the relief energy determine a high morphodynamic potential (Fig. 1). Under these conditions, rich rainfalls that fall during the summer cause drainage on the slopes, torrents and in the river bed, leading to floods and floodings.

The density of fragmentation in this basin is characterized by high values specific to the mountain area, which favour the formation of flow concentration areas. In recent years, massive deforestation has occurred in the basin of the river Bâsca,

\footnotetext{
${ }^{1}$ National Institute of Hydrology and Water Management, Bucharest lidia.salajan@yahoo.com

${ }^{2}$ Hidraulics, Hidraulic Machineries and Enviromental Engineering Bucharest dnistoran@ yahoo.com
} 
which has led to the increase of erosion in the surface, the degree of torrentiality and increased flood risk. An important role is represented by the soil dislocation and the dislodging of the alluvial material to the river and sometimes the production of muddy floods. Human settlements belong to the category of scattered villages, and part of the build-up are being located in river beds, areas vulnerable to floods and floodings (Sălăjan, 2018).

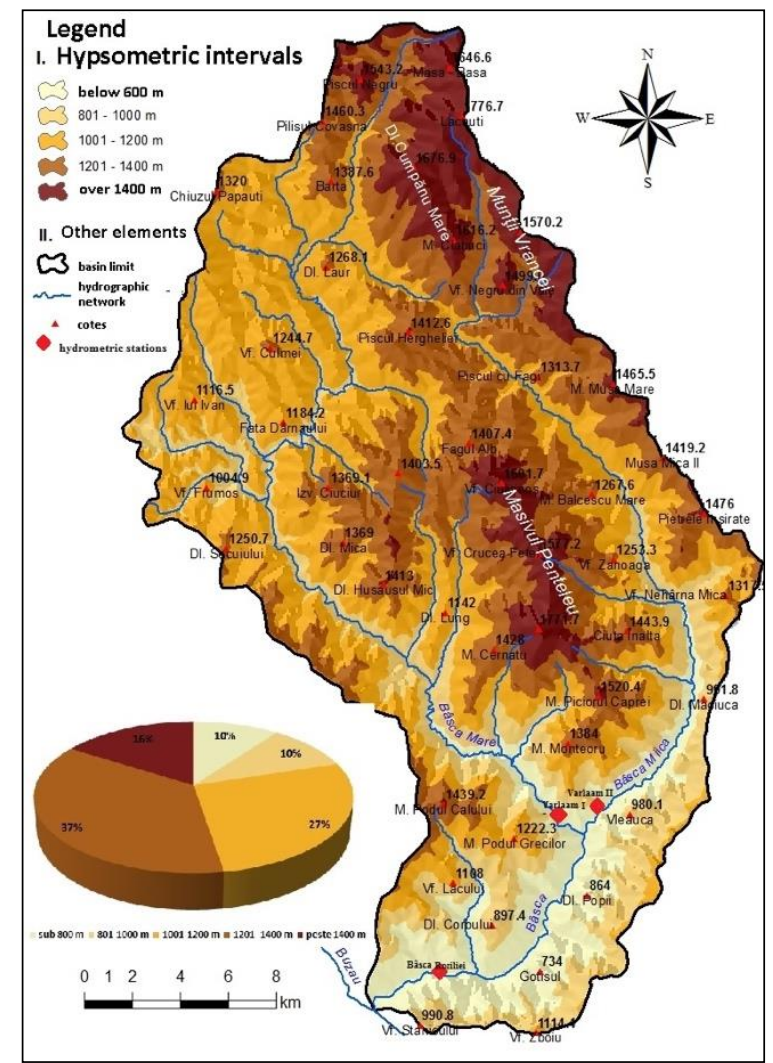

Fig. 1. Hypsometric map of Bâsca River Basin (source: Topographic maps at scale 1: 25000, 1972)

\section{DATA AND METHODS}

The data used in this paper came from two meteorological stations belonging to the studied area (Lăcăuţi and Penteleu) and from three hydrometric stations: Bâsca Roziliei located on the Bâsca River, Varlaam I on the Bâsca Mare River and Varlaam II situated on the Bâsca Mică River (Fig. 1). For the flood analysis and interpretation, we took the primary data (meteorological and hydrological) from each hydrometric station, we made the graphic representations of the floods and the integral volume curves, we determined the characteristic elements of the flood waves based on the 
specific formulas. For the meteorological stations analyzed the graphic representations of the precipitations were made.

\section{RESULTS AND DISCUSSIONS}

\subsection{Factors that have determined floods formation and evolution}

The Bâsca River Basin is located in a moderate temperate continental climate with particularities induced by the orographic barrier due to its geographical location within the Curvature Carpathians. In this mountainous climate, there are sometimes specific foehn processes in the area. The torrential rains that take place during the summer favour the appearance of floods. The main climatic factors that determine the floods and floodings in the Bâsca River Basin are: liquid and solid precipitation, temperatures and snow cover. The precipitation regime in terms of annual quantities varies between 1000 - $1320 \mathrm{~mm}$ and the maximum precipitation in 24 hours ranges between $80-155 \mathrm{~mm}$ during the reference period 1961-2000 (Clima României, 2008).

The annual pluviometric regime at the analyzed stations is characterized by the maximum rainfall values in summer and minimum values during the winter period. The largest amount of precipitation falls in June-July with a torrential character, resulting in floods and floodings.

In Figure 2 is shown a comparison of the monthly average precipitation from 1974 and 1975, years in which there were significant floods, with the multiannual monthly averages $(\mathrm{mm})$ at the Lăcăuţi meteorological station. It can be noticed that the largest amount of rainfall occurred in May-July, which coincides with that of floods. Also, comparing the monthly average rainfalls from Lăcăuţi meteorological station in 1975, with the monthly multiannual averages, it is observed that during most months, the average precipitation in 1975 was around and above the monthly multiannual averages, with the exception of May and July when the precipitation values were far above these and generated the highest floods in the Bâsca River Basin. At Lăcăuţi meteorological station there were precipitations of $281 \mathrm{~mm}$ in July 1975 and $193 \mathrm{~mm}$ respectively in June 1974.

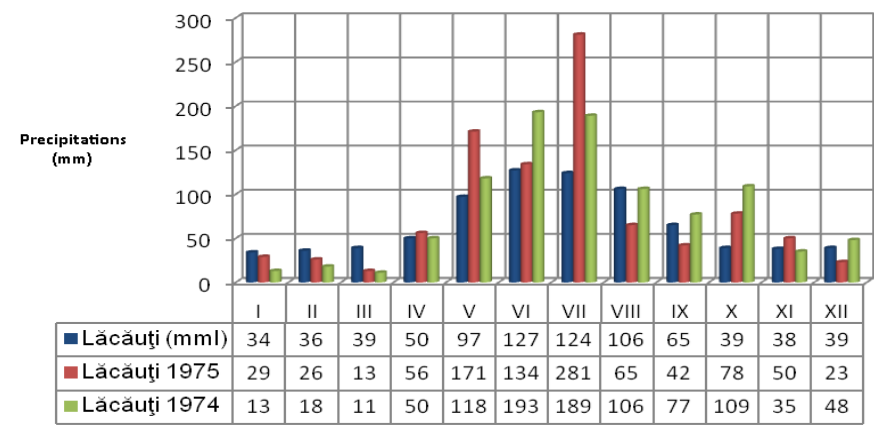

Fig. 2. Distribution of monthly multiannual average precipitation at Lăcăuţi meteorological station (1961-2000), compared to the monthly average precipitation from 1974 and 1975 (source: Clima României, 2008) 
The precipitation amounts recorded in 24 hours (average $110 \mathrm{~mm}$ ) at the pluviometric stations and the Lăcăuţi meteorological station and due to the excess of the previous soil humidity, of the local thermal convection led to high water speeds on the slopes and contributed to the formation of historical floods in the Bâsca basin.

\subsection{The flood of June 1974 and its characteristics}

The flood produced on the Bâsca Mare River at the Varlaam I hydrometric station between 11 and 15 June 1974 was a historic single-peak flood with a maximum flow rate of $300 \mathrm{~m}^{3} / \mathrm{s}$. The maximum flow rate was 40 times higher than the multiannual average flow over the period 1956-2010 $\left(7.54 \mathrm{~m}^{3} / \mathrm{s}\right)$ and had an exceeding probability of approx. 10\% (Cadastrul de maxime, 1988; Cadastrul Apelor din România al debitelor maxime, 2002). The characteristic elements of the flood wave are shown in Table 1. The flow at the Varlaam I hydrometric station on the Bâsca Mare River was determined by an average rainfall of $264.4 \mathrm{~mm}$, the increasing time was 24 hours and the total flood duration was 114 hours. The total flood volume was 39.9 million $\mathrm{m}^{3}$, the equivalent water layer $-156 \mathrm{~mm}$, and the shape coefficient was 0.35 (Sălăjan, 2018).

The moment of the flood started at hour 15:00 on 11.06.1974, the date of the peak flow recording occurred on 12.06.1974 between hours 12:00-15: 00 and the end of the flood occurred on the date of 16.06.1974 at hours 12:00 (Fig. 3).

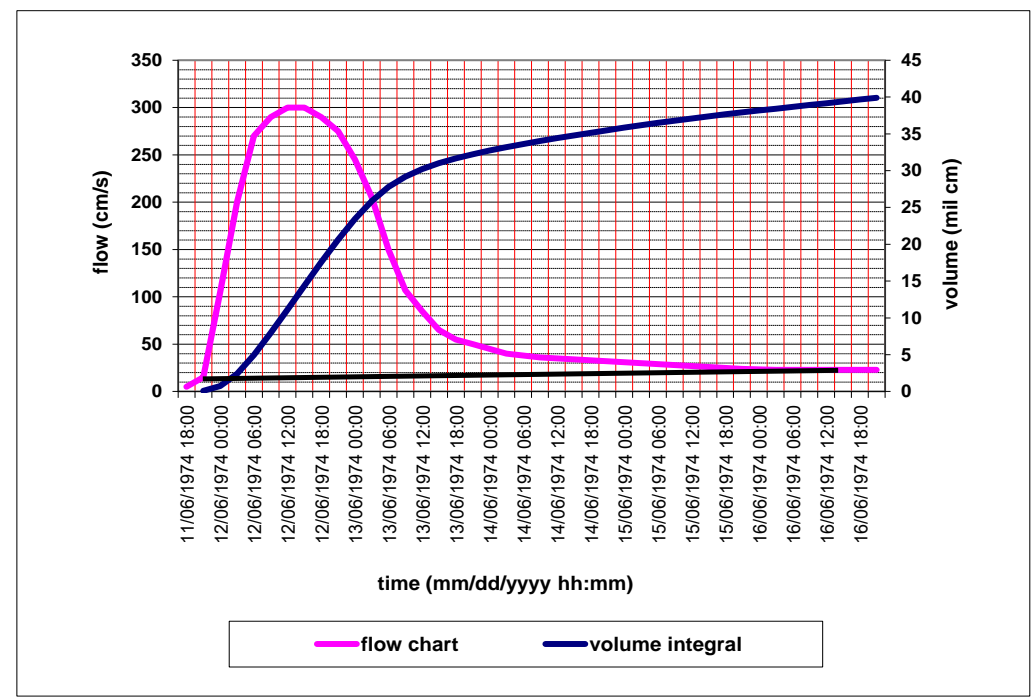

Fig. 3. The flood on the Bâsca Mare River at Varlaam I hydrometric station, between 1115.06.1974 and the volume integral (data source: INHGA)

The flood produced on the Bâsca Mică River at the Varlaam II hydrometric station between 11 and 16 June 1974 had a single peak with a maximum flow rate of $114 \mathrm{~m}^{3} / \mathrm{s}$ (Fig. 4, Table 1). 


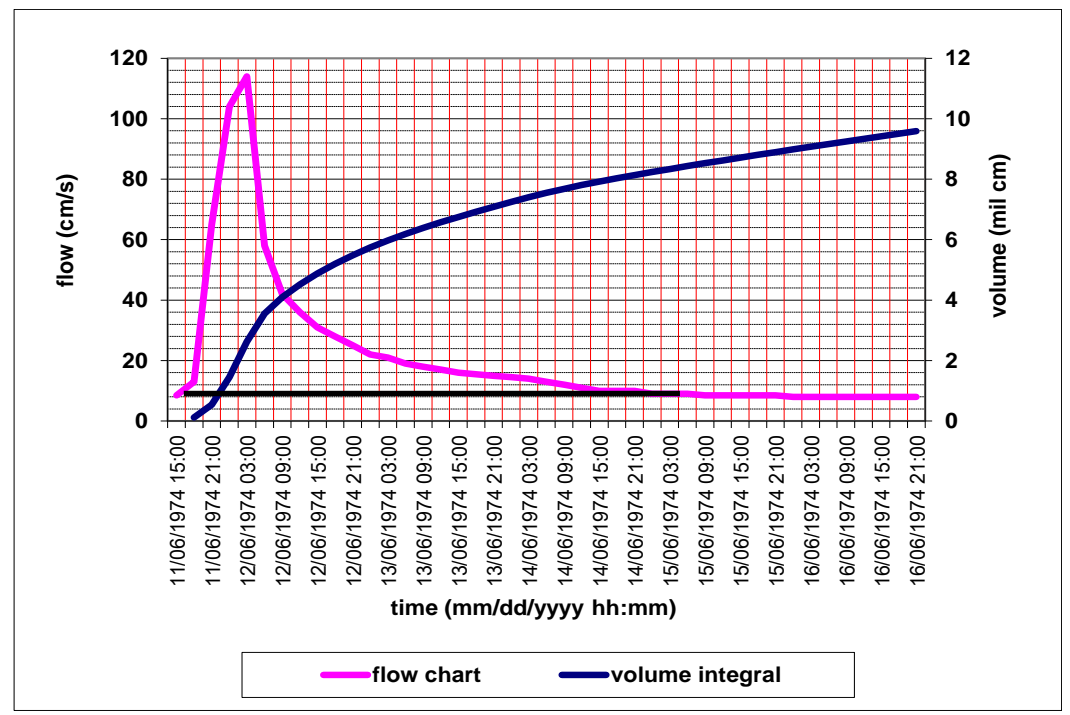

Fig. 4. The flood from the Bâsca Mică River at the Varlaam II hydrometric station, between 11-16.06.1974 and Volume Integral (data source: INHGA)

The maximum flow rate was 32 times higher than the multiannual average flow over the period 1973-2010 (of $3.43 \mathrm{~m}^{3} / \mathrm{s}$ ) and had the exceeding probability below 10\% (Cadastrul de maxime, 1988; Cadastrul Apelor din România al debitelor maxime, 2002).

The flood was determined by an average precipitation of $138 \mathrm{~mm}$, the increasing time was 12 hours, and the flood duration was 84 hours. The flood volume was 9.6 million $\mathrm{m}^{3}$, the equivalent water layer was $32.8 \mathrm{~mm}$, and the shape coefficient was 0.39 (Sălăjan, 2018).

The moment of the flood started at hour 15:00 on 11.06.1974, the date of the peak flow recording occurred on 12.06.1974 at hour 3:00 and the end of the flood occurred on 15.06.1974 at hour 6:00.

The flood produced on the Bâsca River at the Bâsca Roziliei hydrometric station between 11 and 16 June 1974 had a single peak with a recorded maximum flow of $345 \mathrm{~m}^{3} / \mathrm{s}$ (Fig. 5).

The maximum flow rate was 29 times higher than the average annual flow rate of $12.1 \mathrm{~m}^{3} / \mathrm{s}$ between 1953 and 2010 and had an exceeding probability of 10\% (Cadastrul de maxime, 1988; Cadastrul Apelor din România al debitelor maxime, 2002).

The flood was determined by an average rainfall of $146.2 \mathrm{~mm}$, with an increasing time of 24 hours, and a flood duration of 120 hours. The total flood volume was 49.5 million $\mathrm{m}^{3}$, the equivalent water layer was $65.8 \mathrm{~mm}$, and the shape coefficient was 0.32 (Table 1). 
Table. 1. The characteristic elements of the flood waves produced in the Bâsca River Basin in the years 1974 and 1975 (data source: INHGA)

\begin{tabular}{|c|c|c|c|c|c|c|}
\hline $\begin{array}{l}\text { Floods' elements and its } \\
\text { measurement units }\end{array}$ & $\begin{array}{c}\text { Bâsca } \\
\text { Mică } \\
1974\end{array}$ & $\begin{array}{c}\text { Bâsca } \\
\text { Mare } \\
1974\end{array}$ & $\begin{array}{l}\text { Bâsca } \\
1974\end{array}$ & $\begin{array}{c}\text { Bâsca } \\
\text { Mică } \\
1975\end{array}$ & $\begin{array}{c}\text { Bâsca } \\
\text { Mare } \\
1975\end{array}$ & $\begin{array}{c}\text { Bâsca } \\
1975\end{array}$ \\
\hline Tcr (Increasing time) (hours) & 12 & 24 & 24 & 15 & 21 & 24 \\
\hline $\begin{array}{l}\text { Tdecr (Decreasing time) } \\
\text { (hours) }\end{array}$ & 72 & 90 & 96 & 45 & 90 & 93 \\
\hline $\begin{array}{l}\text { Tt (Flood duration) } \\
\text { (hours) }\end{array}$ & 84 & 114 & 120 & 60 & 111 & 117 \\
\hline Q (base flow) $\left(\mathrm{m}^{3} / \mathrm{s}\right)$ & 11.5 & 14 & 21 & 14.5 & 2.5 & 20 \\
\hline Qmax (maximum flow) (m³/s) & 114 & 300 & 345 & 392 & 600 & 960 \\
\hline W (flood volume) $\left(\mathrm{m}^{3} \mathbf{1 0}^{6}\right)$ & 9.6 & 39.9 & 49.5 & 23.6 & 48 & 74 \\
\hline$\gamma$ (shape coefficient) & 0.39 & 0.35 & 0.32 & 0.29 & 0.2 & 0.18 \\
\hline$q$ (specific flow) $\left(\mathrm{l} / \mathrm{s}^{*} \mathrm{~km}^{2}\right)$ & 485 & 706 & 454 & 1668 & 1415 & 1238 \\
\hline$\alpha$ (flow coefficient) & 0.30 & 0.59 & 0.45 & 0.42 & 0.45 & 0.43 \\
\hline Flown water layer (mm) & 32.8 & 156 & 65.8 & 57.8 & 113.2 & 98.6 \\
\hline
\end{tabular}

The moment of the flood started at hour 15:00 on 11.06.1974, the date of the peak flow recording occurred on 12.06.1974 at hour 15:00 and the end of the flood occurred on 16.06.1974 at hour 18:00.

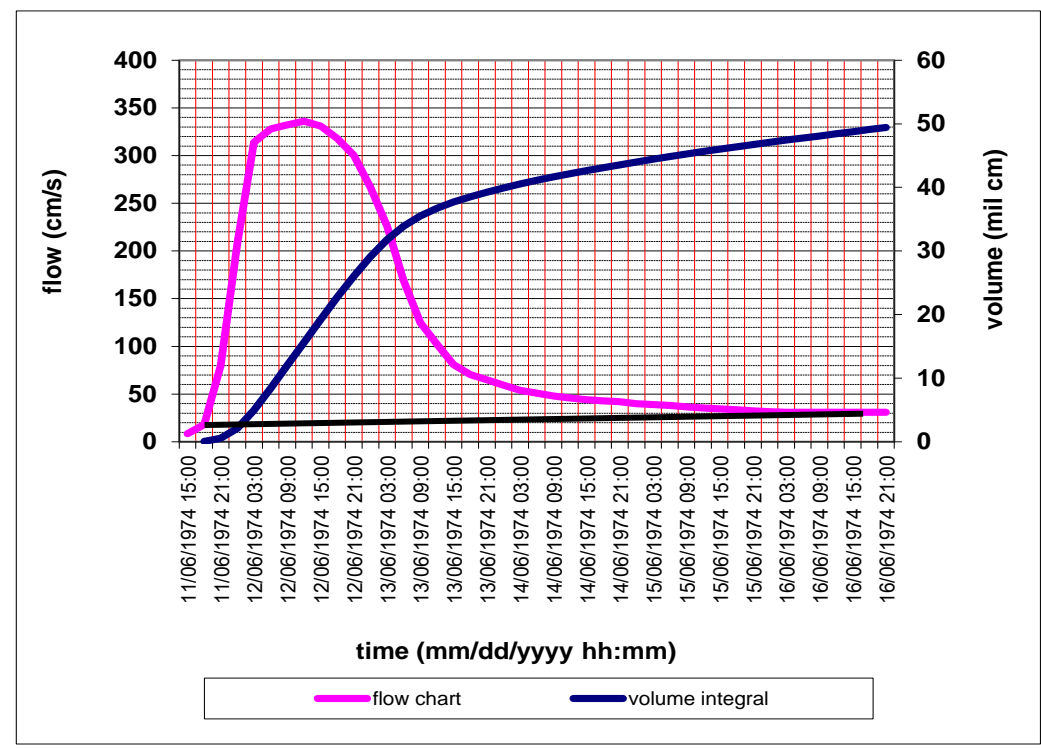

Fig. 5. The flood from Bâsca River at Bâsca Roziliei hydrometric station, between 11 16.06.1974 and the volume integral (data source: INHGA)

The precipitations that generated the 1974 and 1975 floods were front precipitations generated by cyclones formed in the Mediterranean Sea, cyclones that usually travel from the west to the east of the country, sweeping the Getic, Oltenia 
and Curvature Sub-Carpathians, and then is extinguished in the south of Moldova towards its north.

This sequence usually causes a uniform rainfall on the surface of the entire Bâsca hydrographic basin. In such conditions, simple floods are formed on the Bâsca Mare and Bâsca Mică rivers, and their composition results in a single-peak flood. Because the surface of the Bâsca Mare basin is double that of the Bâsca Mică basin, the flood on the has higher concentration times and a higher volume compared to the Bâsca Mică River, the start of the occurrence of floods on both the Bâsca Mică and Bâsca rivers is almost the same, while the flood on the Bâsca Mare River is produced with a certain gap.

The occurrence moment of the maximum flood is the same on both rivers, and on the Bâsca Mică River it occurred 18 hours before (Sălăjan, 2018) (Fig. 6). By composing the maximum flows recorded at the two hydrometric stations Varlaam I on Bâsca Mare and Varlaam II on Bâsca Mică $\left(114 \mathrm{~m}^{3} / \mathrm{s}\right.$ and $300 \mathrm{~m}^{3} / \mathrm{s}$ respectively), results a discharge of $414 \mathrm{~m}^{3} / \mathrm{s}$; at Bâsca Roziliei the recorded flow was $345 \mathrm{~m}^{3} / \mathrm{s}$, having a difference of $69 \mathrm{~m}^{3} / \mathrm{s}$ compared to the flow rate resulting from the composition, due to the fluctuation of the floods on the two tributaries (Sălăjan, 2018).

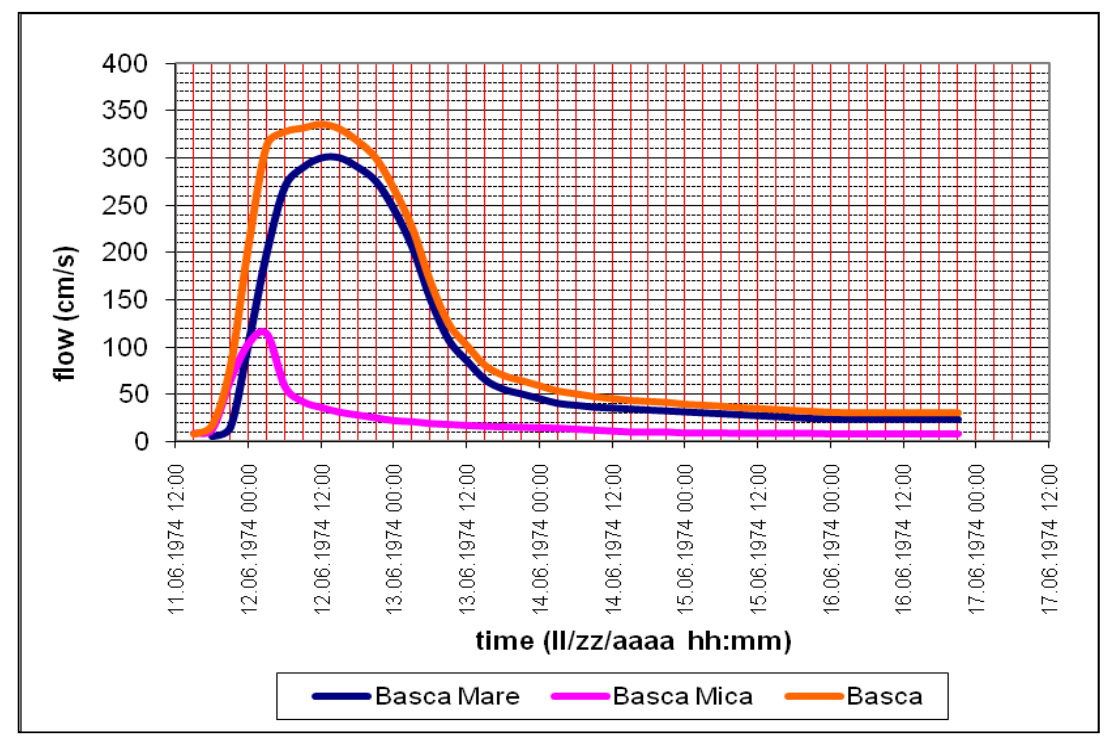

Fig. 6. The composition of the flood waves at the Bâsca Roziliei hydrometric station, on the Bâsca River between 11-17 June 1974 (data source: INHGA)

\subsection{The flood of July 1975 and its characteristics}

On July 2, 1975, significant rainfall was recorded at the pluviometric stations: Comandău (133 mm), Bâsca Roziliei $(135 \mathrm{~mm})$, Varlaam $(103 \mathrm{~mm}), 101 \mathrm{~mm}$ at Lăcăuţi meteorological station (Minea, 2012; ANM). 
These precipitations led to rapid flow on the slopes, torrents, streams, and contributed to the formation of the historical floods from July 1975.

In the July 1975 flood analysis, it can be seen that the flood waves both on the Bâsca Mare and Bâsca Mică rivers have a gap of less than 2 hours and on the Bâsca River at the Bâsca Roziliei hydrometric station a maximum flow of $960 \mathrm{~m} / \mathrm{s}$, which represents the historical flow (Sălăjan and Stanciu, 2010).

Thus, the flood produced on the Bâsca Mare River at the Varlaam I hydrometric station between 01 and 07 July 1975, was a historic flood with a single peak, with a maximum flow rate of $600 \mathrm{~m}^{3} / \mathrm{s}$ (Fig. 7, Table 1).

The maximum flow rate was 80 times higher than the multiannual average flow over the period 1956-2010 $(7.54 \mathrm{~m} / \mathrm{s})$ and had an exceeding probability of 3\% (Cadastrul de maxime, 1988; Cadastrul Apelor din România al debitelor maxime, 2002) (Sălăjan, 2018).

The flood was determined by an average rainfall of $251 \mathrm{~mm}$, the increasing time was 21 hours and the flood duration was 111 hours. The total flood volume was 48 million $\mathrm{m}^{3}$, the equivalent water layer was $113.2 \mathrm{~mm}$ and the shape coefficient was 0.45 (Table 1).

The moment of the flood started at hour 21:00 on 1.07.1975, the date of the peak flow recording occurred on 2.06.1975 at hour 18.00 and the end of the flood occurred on 6.07.1975 at hour 12:00.

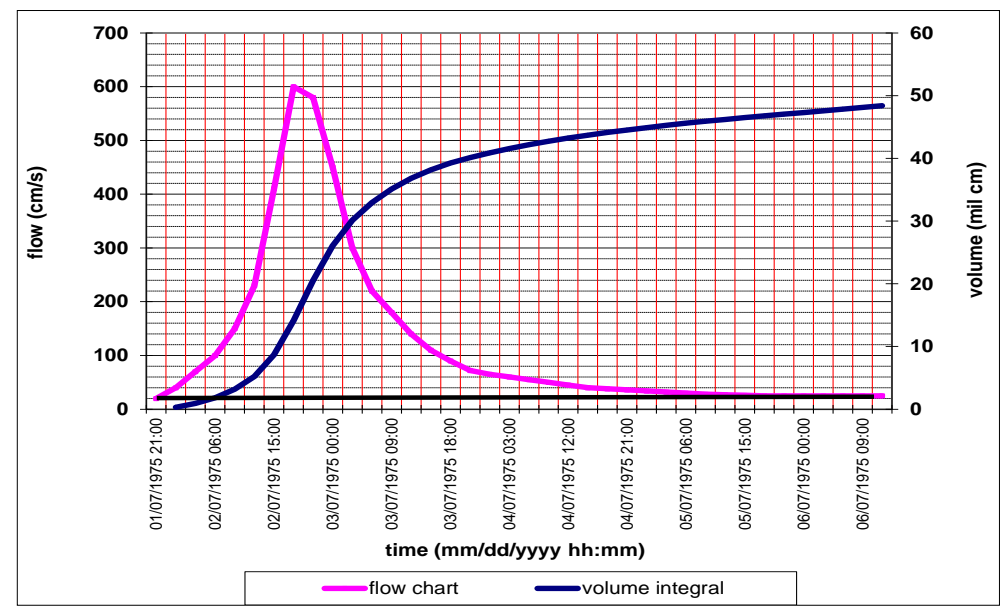

Fig. 7. The flood from Bâsca Mare River at Varlaam I hydrometric station, between 0107 July 1975 and the volume integral (data source: INHGA)

The flood produced on the Bâsca Mică River at the Varlaam II hydrometric station between 02 and 04 July 1975 was a historic flood with a single peak with a maximum flow rate of $392 \mathrm{~m}^{3} / \mathrm{s}$ (Fig. 8). The maximum flow rate was 115 times higher than the average multiannual flow over the period 1973-2010 of $3.43 \mathrm{~m}^{3} / \mathrm{s}$ and had an exceeding probability of 3\% (Cadastrul de maxime, 1988; Cadastrul Apelor din România al debitelor maxime, 2002).

The flood was determined by an average rainfall of $138 \mathrm{~mm}$, the increasing time was 15 hours and the flood duration was 60 hours. The flood volume was 23.6 million $\mathrm{m}^{3}$ (of which $\mathrm{Wt}$ was 23.6 million $\mathrm{m}^{3}$ and Wbase was 0.9 million $\mathrm{m}^{3}$ ), the equivalent water layer was $57.8 \mathrm{~mm}$, and the shape coefficient was of 0.29 (Tab.1). 
The moment of the flood started at hour 6:00 on 2.07.1975, the date of the peak flow recording occurred on 2.06.1975 at hour 21.00 and the end of the flood occurred on 4.07.1975 at hour 18:00.

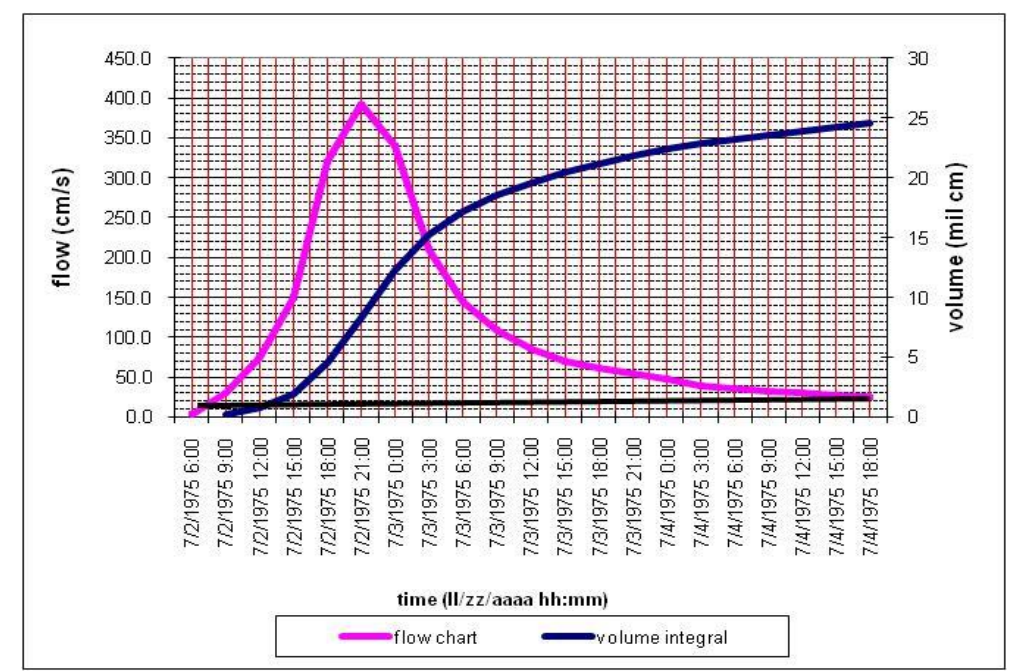

Fig. 8. The flood from Bâsca Mică River at Varlaam II hydrometric station, from 02 to 04 July 1975 and the volume integral (data source: INHGA)

The flood produced on the Bâsca River at the Bâsca Roziliei hydrometric station in July 01-07 1975 was a historic flood with a single peak with a maximum flow rate of $960 \mathrm{~m}^{3} / \mathrm{s}$ (Fig. 9). The maximum flow was 78 times higher than the multi-annual average flow between 1953 and $2010\left(12.1 \mathrm{~m}^{3} / \mathrm{s}\right)$ and had an exceeding probability of approx. 2\% (Cadastrul de maxime, 1988; Cadastrul Apelor din România al debitelor maxime, 2002).

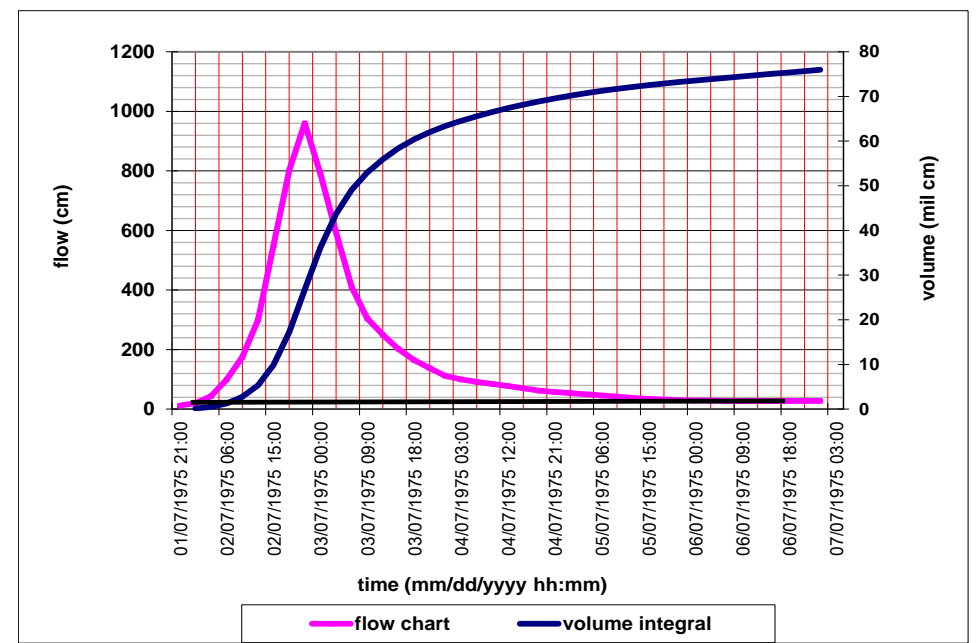

Fig. 9. The flood from Bâsca River at Bâsca Roziliei hydrometric station between July 1 and July 7, 1975 and the volume integral (data source: INHGA) 
It was determined by an average rainfall of $229 \mathrm{~mm}$, the increasing time was 24 hours and the flood duration was 117 hours. The total flood volume was 74 million $\mathrm{m}^{3}$, the equivalent water layer was $98.6 \mathrm{~mm}$, and the shape coefficient was 0.18 (Table 1).

The moment of the flood started at hour 21:00 on 1.07.1975, the date of the peak flow recording occurred on 2.06.1975 at hour 21.00 and the end of the flood occurred on 6.07.1975 at hour 18:00.

As mentioned earlier in the genesis of flood generation in 1975, the causes of these floods were the circulation of air masses from the west that caused the movement of significant amounts of precipitation, but also the influence of local conditions. In the hydrographic basin of Bâsca River, the occurrence moment of floods at all hydrometric stations was about the same. The occurrence moment of peak floods in Bâsca Mică basin started 6 hours before the production of those in the Bâsca Mare and Bâsca basins that took place at the same time.

By the composition of the flows from the Bâsca Mare and Bâsca Mică rivers, a flow of $992 \mathrm{~m}^{3} / \mathrm{s}$ is obtained, compared to the flow recorded at Bâsca of $960 \mathrm{~m}^{3} / \mathrm{s}$, the rest of the flow value being from the rest of the basin (Fig. 10).

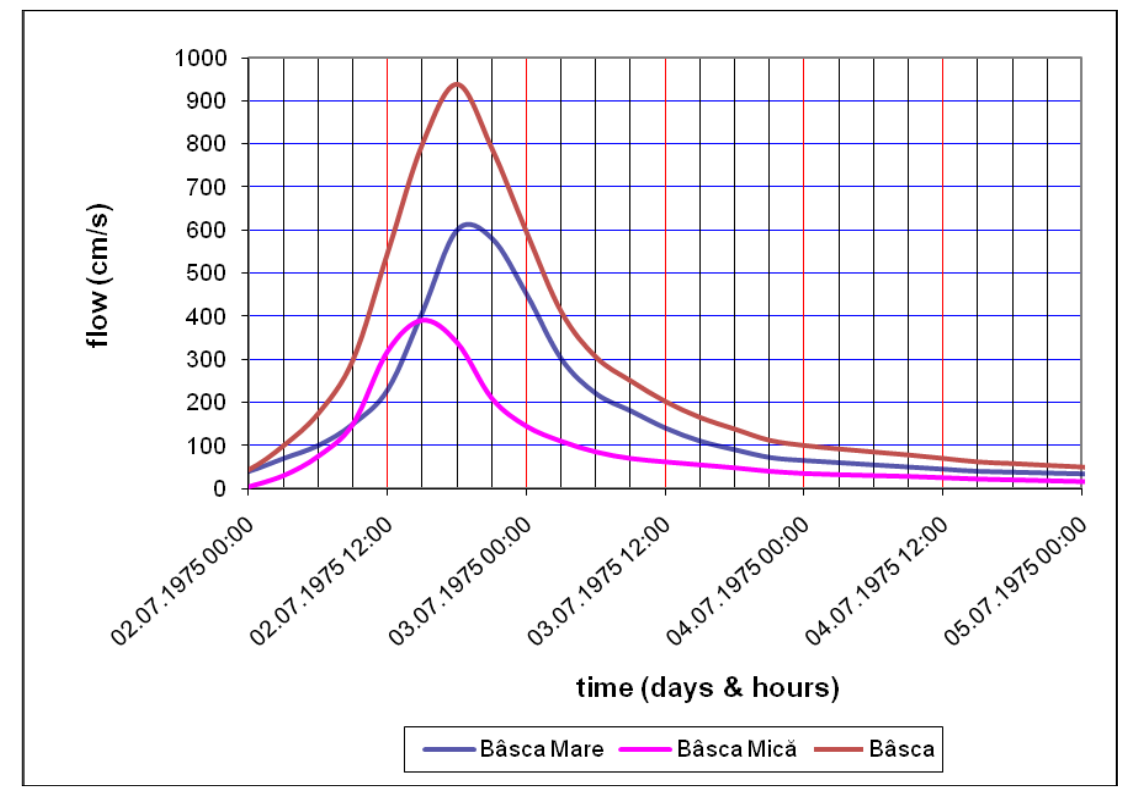

Fig. 10. Composition of flood waves at the Bâsca Roziliei hydrometric station on the Bâsca River from 02 to 05 July 1975 (source: INHGA)

\section{THE CONSEQUENCES OF FLOODS AND FLOODINGS IN BÂSCA RIVER BASIN}

The floods and floodings produced in the Bâsca River Basin have caused significant material damage. They affected: people's lives, households and household annexes, animals and birds, infrastructure elements (transport: county, 
communal and forest roads, bridges, footpaths) and agricultural land. In 1975, floods and floodings affected 200 homes and household annexes, 100 animals and birds. It also affected the transport infrastructure on county roads $(1 \mathrm{~km})$, communal roads $(15 \mathrm{~km})$ and forest roads $(25 \mathrm{~km}), 2$ bridges and 10 footpaths, and flooded agricultural land (300 ha) and there were 5 losses of human lives. All of these have had serious consequences on human health and on the environment (Aquaproiect 2006, Minea, 2012, Sălăjan, 2018).

\section{CONCLUSIONS}

The analyses are complex, they concern: the particularities of the natural and anthropic factors that generated and favoured the production of the floods; causes and characteristics of floods; their consequences and the risk management apects. The floods and floodings on the Bâsca River Basin are a consequence of the climatic conditions, the thermal convection during the summer period, the retrograde cyclones formed in the Black Sea and the influence of the anthropic factor. The high impermeability degree of the rocks from this basin does not allow a high infiltration in the ground, increasing the volume of water feeding the rivers, which accelerates water flow on the slopes and its rapid concentration on riverbeds. Historical floods from 1974 and 1975 in this basin are single floods and were determined by precipitation with values between $150-270 \mathrm{~mm}$ and local conditions. Solutions to diminish the hydrological and geomorphological risks are: afforestation of cleared surfaces and proper use of land on the slope, the execution of rainwater drainage works in the countryside (gutters, drainage ditches) and their maintenance at the level of the minor bed, land development works of the major river beds and slopes etc.

\section{REFERENCES}

1. Minea, G. (2012), Bazinul hidrografic al râului Bâsca - Studiul de hidrogeografie, Teză doctorat, Universitatea din Bucureşti - Facultatea de Geografie, ISBN 978 -606 - 16 - 0134 - 9 .

2. Posea, G., Ielenicz, M. (1971), Judeţul Buzău, Editura Academiei Republici Socialiste România).

3. Sandu, I., Pescaru, V.I., Poiană Geicu, A., Cândea, I., Țâștea, D. (2008), Clima României. Factorii genetici ai climei. Parametrii climatici ai teritoriului României, Editura Academiei Române, ISBN 978 - 973 - 27- 1674 - 8, Administrație Națională de Meteorologie, Bucureşti.

4. Sălăjan L., Stanciu P. (2010), Hydological risk phenomena in the Bâsca Roziliei River Basin „Conference on "Water Observation and Information System for Decision Support." The Fourth International Scientific Conference BALWOIS 25-29 Mai 2010, Ohrid, Republic of Macedonia, Absracts Volume I, (http://www. Balwois.com /balwois/admnistration/full_paper/ffp-2099.pdf), ISBN 978-608-4510-03-1.

5. Sălăjan L. (2018), Viiturile şi inundaţiile de la: prognoză la management, Teză de doctorat, Universitatea Bucureşti - Facultatea de Geografie, în curs de publicare. 
6. *** (1988), Cadastrul de maxime, IMH, Bucureşti.

7. *** (2002), Cadastrul Apelor din România al debitelor maxime, Editura Romcart, București.

8. *** (2006), Proiect Aquaproiect Lucrări de apărare împotriva inundaţiilor din b.h.Buzău, aval de acumularea Siriu, pentru subbazinele Bâsca Mare şi Bâsca Roziliei, jud. Buzău, Proiect nr. 3793, Proiect tehnic, Vol. I, Lucrări hidrotehnice, S.C. Aquaproiect S.A., Bucureşti. 